\title{
Regulation of Business Licenses for Micro, Small, and Medium Enterprises through One Single Submission (OSS) and Issues
}

\author{
Sri Bakti Yunari ${ }^{1}$, Rahmat Santoso ${ }^{2}$, Harto $^{3}$, Ramadhana Anindyajati Bachry ${ }^{4}$ \\ \{sri.by@trisakti.ac.id ${ }^{1}$, rahmatsantoso@trisakti.ac.id ${ }^{2}$, harto@trisakti.ac.id ${ }^{3}$, ramadhana@trisakti.ac.id ${ }^{4}$ \} \\ Universitas Trisakti, Jakarta, Indonesia ${ }^{1,2,3,4}$
}

\begin{abstract}
The purpose of this article is to analize the Government's Efforts in Facilitating Small, Micro and Medium Enterprises (MSMEs) to have Business Licenses and to explain in more detail about Law Enforcement against MSMEs that do not have Business Permits in Indonesia. Law Enforcement Efforts in licensing arrangements are divided into two efforts, namely law of administrative and criminal law enforcement. The novelties in this paper are the Government's Efforts to Facilitate MSMEs to obtain Risk-based Business Permits and law enforcement against MSMEs that do not have a business license. Before law enforcement efforts are carried out, the government makes it easy for business actors to register and manage business permits, which specifically for micro and small businesses are free of charge.
\end{abstract}

Keywords: Micro Small Medium Entreprise; Business Permit; Enforcement Efforts

\section{Introduction}

The existence and empowerment of Micro, Small and Medium Enterprises (MSMEs) in Indonesia has proven to be a driving force for the national economy that has contributed and played an important role in absorbing a large number of workers, compared to other business entities. Where MSMEs have contributed and absorbed more labor, which increased from $96.99 \%$ to $97.22 \%$ in $2012-2017$. This shows that MSMEs can reduce unemployment and overcome poverty. Hence, MSMEs are proven to have made a significant contribution in strengthening small, medium and micro enterprises as pillars of the nation's economic development. The existence and empowerment of MSMEs in Indonesia has proven to be a driving force for the national economy that has contributed and played an important role in absorbing a large number of workers, compared to other business entities. MSMEs have contributed and absorbed more labor, which increased from $96.99 \%$ to $97.22 \%$ in $2012-2017$. This shows that small, medium and micro enterprises can reduce unemployment and overcome poverty. Hence, MSMEs are proven to have made a significant contribution in strengthening small, medium and micro enterprises as pillars of the nation's economic development [1] [2]. 
The development of MSME in Indonesia has increased rapidly in the past 10 years. The 2017 data of the RI Ministry of Cooperatives and Small and Medium-sized Enterprises indicate that the number of MSME units accounted for approximately $99.99 \%$ of the total (62.9 million units) of Indonesian business participants. Among them, large enterprises only account for about $0.01 \%$ or about 5,400 business units. Similarly, micro-enterprises absorb about 107.2 million laborers (89.2\%), and small enterprises absorb about 5.7 million laborers (4.74\%). Therefore, there are approximately 3.73 million workers $(3.11 \%)$ in medium-sized enterprises. At the same time, large enterprises only absorbed about 3.58 million workers. This means that small, medium and micro enterprises absorb about $97 \%$ of the labor force in the country, while large enterprises only absorb about $3 \%$ of the total labor force in the country. The data shows that the contribution of MSMEs in creating jobs in Indonesia and is very dominant [3]. As well as in other countries in the world, such as Malaysia [4], Australia [5], Ethiopia [6] [7], Africa Selatan [8] [9], India [10] [11], Nigeria [12] [13], Taiwan [14], New Zealand [15] and China [16].

The existence of Small, Micro and Medium Enterprises has been regulated through Law Number 20 of 2008 concerning Small, Micro and Medium Enterprises ("MSMEs Law"). However, in developments, regulations for MSMEs actors also refer to Law Number 11 of 2020 concerning Job Creation (UUCK) and Government Regulation Number 7 of 2021 concerning Ease, Protection, and Empowerment of Cooperatives and MSMEs ("GR No. $7 / 2021$ "). It is hoped that the change in business capital can further foster community economic growth, and MSMEs can make a significant contribution to the development of the Indonesian economy, especially during the current pandemic. The positive impact of MSMEs is that they can move the wheels of the nation's economy and have the potential to reduce the number of unemployed. MSMEs are one of the potential for job expansion to overcome unemployment and poverty, as well as foster the spirit and culture of entrepreneurship and entrepreneurship for the perpetrators. In this regard, MSMEs can be said to be the backbone and foundation of the populist economy, so that in the event of an economic crisis, if MSMEs are strong, the economy will also remain strong.

One aspect that deserves attention from the perspective of MSMEs is the aspect of legality and licensing, then MSMEs actors become more aware of the law, which then completes their legality and business licensing more competitive and open up opportunities for investors to invest and make it easier to invest. apply for business capital loans to banks. The existence of new rules related to licensing for MSMEs as regulated in UUCK which was then followed by the issuance of delegation regulations through Goverment Regulation No. 5/2021 concerning the Implementation of Risk-based Business Licensing, where technically licensing for MSMEs must be carried out through the Electronically Integrated Business Licensing Service, known as the 'Electronically Integrated Business Licensing System' (Online Single Submission), hereinafter referred to as OSS, which is an integrated electronic system managed and organized by the OSS Institution for the implementation of Risk-Based Business Licensing. How exactly is the OSS arrangement as a form of business licensing service for risk-based Small, Micro and Medium Enterprises. Then, what are the consequences if Micro, Small and Medium Enterprises do not have a Business License.

\section{Research Method}

The research method used in this article is a normative method. Among them, the research method is normative. It is a legal writing method that aims to obtain library legal 
materials by collecting and analyzing legal materials related to the problem. This article analyzes the secondary legal materials to study the government's efforts to promote small, medium and micro enterprise operating licenses and how to implement laws and regulations related to the small, medium and micro enterprise law. No business license.

\section{Literature Review}

The existence of MSMEs is basically regulated through Law Number 20 of 2008 and its delegation regulations. Then in its development with the birth of Law Number 11 of 2020 concerning Job Creation following the regulation of the delegation of GR 7/2021 regarding the Ease, Protection, and Empowerment of Cooperatives and MSMEs. Based on GR 7/2021 Article 35 paragraph (3), the business capital criteria of MSMEs shall consist of:

a. Micro Business has a business capital of up to a max. of IDR 1,000,000,000.00 (one billion rupiah) excluding land and building for the place of business;

b. Small Business has a business capital of more than IDR 1,000,000,000 (one billion rupiah) up to a max. of IDR 5,000,000,000 (five billion rupiah) excluding land and buildings for business premises; and

c. Medium Enterprises have a business capital of more than IDR 5,000,000,000 (five billion rupiahs) up to a maximum of IDR 10,000,000,000 (ten billion rupiahs) excluding land and buildings for business premises.

Furthermore, the government's commitment as the regulator to improve the ease of doing business in Indonesia has issued regulations that make it easier for business actors to take care of the establishment procedures and business licensing, especially for MSMEs that are carried out Online. Since 2017, through Presidential Regulation Number 91 of 2017 concerning the Acceleration of Business Implementation, the government has issued a policy that encourages acceleration in the processing of business permits. Furthermore, Government Regulation No. 24 of 2018 on "Integrated E-Commerce License Service" or "Online Single Submission" (hereinafter referred to as OSS), the government revoked the promulgation of Presidential Regulation No. 91 of 2017 on "Accelerating Business Implementation".

Electronic Integrated Commercial Licensing Service or OSS is: "A commercial licensing service issued to commercial participants by the OSS agency on behalf of and on behalf of ministers, agency heads, governors or regents/mayors through integrated electronic systems" (point 1) 5 GR Number 24 of 2018), in this case the Investment Coordination Committee was later changed to the Ministry of Investment [17]. Furthermore, through Article 12 of Law Number 11 of 2020 concerning Job Creation, along with the delegation regulations GR Number 5 of 2021 concerning the Implementation of Risk-Based Business Licensing, the provisions regarding the ease of doing business are reaffirmed and the implementation is submitted to the Ministry of Investment (Investment Coordinating Board). As a follow-up, Investment Coordinating Board has issued 3 (three) delegation regulations from GR Number 5 of 2021, namely:

a. Investment Coordinating Board regulations Number 3 of 2021 concerning the Electronically Integrated Risk-Based Business Licensing System;

b. Investment Coordinating Board regulations Number 4 of 2021 concerning Guidelines and Procedures for Risk-Based Business Licensing Services and Investment Facilities;

c. Investment Coordinating Board regulations Number 5 of 2021 concerning Guidelines and Procedures for Supervision of Risk-Based Business Licensing.

Based on these 3 (three) delegation regulations, Investment Coordinating Board hopes that the implementation of OSS throughout Indonesia can be carried out properly through an 
electronically integrated business licensing system through OSS. The implementation of OSS as a means of supporting Ease of Doing Business (EODB) for business actors, especially MSMEs, turned out to have a very significant influence in providing ease of licensing in Indonesia. Based on data released by the World Bank, since the implementation of OSS, the indicator of starting a business in Indonesia has seen an increase in ranking, from level 144 to level 134. Although Indonesia's EODB rating in his presentation on "Doing Business 2019", has decreased by 1 (one) level. in 2020 so that it is at level 73, compared to the previous year's condition which was at level 72. This is inversely proportional to Indonesia's EODB index which increased to 67.96 or increased by 1.42 compared to the previous year [18].

Regarding the ease of business licensing that has been launched by the government in such a massive way through a series of regulations, naturally it must be addressed with maximum understanding by business actors, including MSMEs.

\section{Result and Discussion}

\subsection{The Government's Efforts to Facilitate Micro, Small and Medium Enterprises to Be Able to Have Business Licenses}

Micro, small and medium enterprises (MSMEs) is an economic policy formulated by the government. It is a business activity that can expand employment opportunities, provide a wide range of economic services to the community, and play a role in the process of fairness and equality. The role of increasing people's income, promoting economic growth and achieving national stability. In addition, in the general description of the Law on Small, Medium and Micro Enterprises, national development aims to create a just and prosperous society within the framework of a unified country, in accordance with the "Pancasila" and the 1945 Constitution of the Republic of Indonesia and amendment, in terms of material and Equally distributed mentally. The Republic of Indonesia, which is independent, united, and sovereign, has a safe, orderly, and vibrant national life in an independent, friendly, and peaceful environment. The characteristics of MSMEs are as follows:

a. The commodity/commodity category of the business is not always fixed and can change at any time;

b. The place of business is not always fixed, it can be changed at any time;

c. Not even simple financial management, and did not separate family finances from corporate finances;

d. Human resources (entrepreneurs) have not enough entrepreneurial spirit;

e. The average level of education is relatively low;

f. Generally speaking, they cannot use banking services, but some of them can use non-bank financial institutions;

g. Generally, there is no business license or other legal requirements, including tax number. Regarding the characteristics of MSMEs in point $g$ above, that here is related to business licenses and other legal requirements, where there are still many MSMEs that do not have business licenses, even though it is an important requirement in establishing a business activity in the industrial sector. MSMe activities need to be carried out comprehensively, optimally, and sustainably through the development of a conducive business climate, providing business opportunities, support, protection, and business development as widely as possible, so as to be able to improve the position, role, and potential of MSMEs in realizing economic growth, equity and increasing people's income, creating jobs, and alleviating 
poverty [19]. The development of MSME activities also means encouraging the economy for the community by increasing income so that opportunities to improve living standards are also increasingly open, opportunities to get education, so it is very necessary and improved in order to increase public awareness of the environment to maintain and manage the environment around their environment.

In the MSMEs Law, The legislature Furthermore neighborhood administrations temporary a benefits of the business atmosphere Eventually Tom's perusing Building enactment and approaches coating viewpoints of:

a. Funding;

b. Offices What's more infrastructure;

c. Business information;

d. Partnership;

e. Benefits of the business license;

f. Business opportunities;

g. Profession promotion;

h. Institution support.

Legal protection is 'all efforts to fulfill rights and provide assistance to provide a sense of security to witnesses and/or victims, legal protection of crime victims as part of community protection' [20]. Legal aspects must be able to regulate the impact of development, law is a subsystem in the system of state life [21]. One form of regulation that regulates MSMEs is regulating aspects of business legality, with the existence of legality for MSMEs this will later be beneficial for MSMEs themselves, for example, to access capital from the government/private sector. In addition to capital, one other thing that is no less important in running a business is legality. This is because the legality of the business is proof of compliance with the rule of law which is able to provide protection to the business when problems occur. Legality is needed not only as business capital assistance but also as a condition for applying for capital, and providing legal certainty for investors and banks.

Hence in order to facilitate licensing, the government and local governments are obliged to provide relief from requirements so that they are easily fulfilled by MSMEs, especially those owned by individuals. Prior to the enactment of GR 24/2018, licensing for MSMEs was carried out by organizing a One-Stop Integrated Service whose implementation must be carried out with the principle of simplifying service procedures and types of permits [22]. In its development, with regard to licensing issues, the government has almost resolved, since the enactment of GR 24/2018 which focuses on regulating aspects of electronically integrated business licensing, which with GR 24/2018 will make it easier for business actors to obtain their business licenses. Because the system used is online-based, so it can be reached anywhere and by anyone.

Based on GR 24/2018, "Electronic Integration Business License" or "Online Single Submission" (hereinafter referred to as "OSS") means "commercial license issued by the Minister in OSS format, approved by the head agency, governor or regent/mayor The integrated electronic system sends information to business participants". GR 24/2018 also clarified the meaning PTSP is an integrated service in a single process from the beginning of the application stage to the completion of the service product stage through a door. Onestop integrated service is "a service provided by the government, including licensing and non-licensing. The management process starts from the application stage until the issuance of documents in one place." OSS is a government program designed to improve public services. Reduce the bureaucracy of licensed and non-licensed services, and strive to achieve good governance. 
The purpose and goal is to provide fast, effective, efficient, transparent and legal licensing and non-licensing services, and to realize the rights of the public and investors to obtain licensing services in the licensing field. Therefore, with the existence of OSS, it is easier for commercial entities to register business licenses because the process is not complicated. In the OSS system, the relevant object is "electronic document". An electronic document is "any electronic information created, forwarded, sent, received or stored in analog, digital, electromagnetic, optical or similar forms, which can be seen, displayed and/or heard through a computer or electronic system, including but not limited to text, Sounds, pictures, maps, designs, photos, etc., letters, signs, numbers, access codes, symbols or perforations, have meaning or meaning or can be understood by people who can understand them".

Hence in GR 7/2021 as a derivative regulation and technical regulation of the Job Creation Law (especially on the aspects of convenience, protection, and development of MSMEs), it is regulated that MSMEs in carrying out their business activities must have a Business License. In GR 7/2021, Business Licensing for MSMEs is given based on the level of risk of business activities, namely in the form of:

a. Business registration number (nomor induk berusahal hereinafter referred to as the "NIB"), for low risk business activities;

b. NIB and standard certificate (sertifikat standar), for medium low and medium high risk business activities; and

c. NIB and permit (izin), for high risk business activities.

In addition, in the event that business activities carried out by Micro Businesses and Small Businesses are included in business activities with a medium or high risk level, in addition to being required to have a Business License as referred to above, business actors are required to have a product standard certificate (sertifikat standar produk) and/or a business standard certificate (sertifikat standar usaha). Furthermore, GR 7/2021 also stipulates that Licensing for MSMEs is carried out through an electronically integrated Business Licensing system, which is managed by the institution that manages the electronically integrated Business Licensing. Hence this provision indicates that after the enactment of GR 7/2021, MSMe actors in the licensing aspect will still be based on GR 24/2018 which essentially continues to use the OSS system. While what is meant by "institutions that manage electronically integrated business licensing" are non-ministerial government agencies that carry out government affairs in the field of investment coordination, which are currently named the Ministry of Investment/the Investment Coordinating Board.

Fulfillment of the requirements and procedures for applying for a Business Licensing is carried out in accordance with the norms, standards, procedures, and criteria regulated in government regulations regarding the implementation of a risk-based Business Licensing. The Central Government and Local Governments provide guidance and registration for Micro and Small Businesses to facilitate Business Licensing. Then in carrying out the guidance and registration, the Central Government and Regional Governments shall:

a. Identification and mapping of Micro Business and Small Business based on low, medium, and high risk levels; and

b. Registration of Micro Business and Small Business actors through the OSS system to obtain the NIB.

However, if Micro Business and Small Business actors are unable to access Business Licensing online, Device Department at the sub-district office and/or ward office/village office facilitate the registration of Business Licensing by considering local characteristics. In 
addition, the Central Government and Local Governments provide assistance for Micro Business and Small Business that have obtained NIB. The assistance is carried out for:

a. Increase knowledge on the application of Indonesian National Standards (Standar Nasional Indonesia/ hereinafter reffered to as the "SNI") and Halal Product Guarantee Certification (Sertifikasi Jaminan Produk Halal / hereinafter reffered to as the "SJPH") for Micro Business and Small Business that have just received NIB; and/or

b. Meet the requirements of obtaining standard certificates (sertifikat standar) and/or permit (izin).

The assistance is carried out at least through facilitation technical guidance, consultation, and/or training. Micro Business and Small Business that have just established businesses can directly apply for NIB, standard certificates, and/or permits through OSS. The Central Government administers a single license (perizinan tunggal) for Micro Business and Small Business through the OSS system, including Business License, SNI, and SJPH. If the business activities carried out by Micro Business and Small Business have low risk, they will be given an NIB which also acts as a single license, which acts as identity and legality in carrying out business activities. That single license, standard certificate and/or permit for the Micro Business and Small Business, is valid for the duration of the business activity. Hence there is no expiration date as in the previous era of business licenses and Certificate of Company Registration). This provision regarding the validity period is excluded for halal certificates in accordance with the provisions of the laws and regulations regarding halal product guarantees. Then what is quite important for MSMe actors is that the registration of a single license, the fulfillment of ownership of standard certificate and/or permit, and the extension of the SJPH for Micro Business and Small Business are free of charge. Furthermore, regarding business licensing information, the Indonesian Minister of Cooperatives and MSMEs conveys Business Licensing information to MSMEs as applicants for Business Licensing through online or electronic publication media facilities regarding:

a. requirements that must be met by the applicant;

b. procedures for applying for a business license; and

c. exemption from licensing fees.

\subsection{Legal Sanctions for Micro, Small and Medium Enterprises that Do Not Have a Business License}

Based on GR 24/2018 and GR 7/2021 do not regulate sanctions for MSMEs that do not have a business license. Instead of regulating sanctions for MSMe actors who do not have business licenses, GR 24/2018 through Chapter VIII, actually regulates the imposition of sanctions for Governors and Regents/Mayors who do not provide services for fulfilling Business License Commitments and/or Commercial or Operational Permits in accordance with OSS to Business Actors who have fulfilled the requirements based on the provisions of this GR 24/2018 and the regulations.

However, referring to Law Number 7 of 2014 concerning Trade ("Trade Law") which has been amended by the Job Creation Law, specifically for MSMEs engaged in the trade sector, Article 106 of Trade Law juncto Job Creation Law stipulates that Business Actors who carry out Trading business activities but do not have a Business License in the field of Trading shall be punished with imprisonment for a maximum of 4 (four) years or a fine for a maximum of IDR 10 billion [23]. However, the imposition of criminal sanctions is exempted from violations committed by business actors and/or low-risk and medium-risk activities, for which they are subject to administrative sanctions in the form of: 

a. Written warning;
b. Withdrawal of goods from distribution;
c. Temporary suspension of business activities;
d. Warehouse closure;
e. Fine; and/or
f. Revocation of Business License.

\section{Conclusion}

MSME actors in general do not feel the need to have a business license, because in practice if the business license is not fulfilled then the majority of the business fields running by MSMe actors can still run their business, especially for Micro Enterprises, there has not been felt the imposition of administrative sanctions for those who do not have a license. Many factors affect this problem, one of which is constrained by the ignorance of business actors regarding the licensing application process in question, in addition to the existence of MSMe actors that a fee will be paid if a permit is issued. Taking into account that the policies made by the government have been quite effective, among others with the PTSP system which was later refined with the OSS system through the enactment of a statutory regulation regarding Electronic Integrated Business Licensing or Online Single Submission, then it is then simplified and made easier again with Job Creation Law and GR 7/2021. So with the renewal of these laws and regulations, it is hoped that business licensing problems can be facilitated and made easy because through online only these permits and licenses can be obtained by MSMe actors. Meanwhile, legal sanctions in the regulation of business licenses are divided into 2 (two) efforts, namely law enforcement through administrative sanctions and criminal sanctions. In administrative law sanctions have the aim of restoring the situation. Regarding the authority to give legal sanctions that are owned by the licensor, in this case it depends on the agency in each field, and the instruments used can be in the form of sanctions or supervision.

\section{References}

[1] J. Papilaya, T. R. Soisa, and H. Akib, "The Influence of Implementing The Strategic Policy In Creating Business Climate, Business Environment And Providing Support Facilities Towards Business Empowerment On Small Medium Craft Enterprises In Ambon Indonesia," Int. Rev. Manag. Mark. Mersin, vol. 5, no. 2, 2015.

[2] Gunartin, "Strengthening MSMEs as Pillars of Building the Nation's Economy," EDUKA J. Educ. Law Bus., vol. 1, no. V, 2017.

[3] A. I. Taufik, "Evaluation of Regulations in Creating Business Ease for MSMEs," Rechtsvinding J., vol. 6, no. 3, 2017.

[4] E. M. A. Engku A. A., "Small Medium Enterprises (SMEs) business owner's wellbeing and business growth in Malaysia," Geografia, vol. 16, no. 4, 2020.

[5] R. Wiesner and B. Millett, "Strategic approaches in Australian SMEs: Deliberate or emergent?," J. Manag. Organ., vol. 18, no. 1, pp. 98-122, 2012.

[6] W. Amhaa and T. Woldehanna, "Policy and Regulatory Challenges Militating Against the Development of Youth-Owned Micro and Small Enterprises in Ethiopia," East. Afr. Soc. Sci. Res. Rev., vol. 32, no. 2, pp. 23-52, 2016. 
[7] P. Bekele, E., Jacobs, "Women Entrepreneurship in Micro, Small and Medium Enterprises: The Case of Ethiopia," J. Int. Womens. Stud., vol. 10, no. 2, pp. 3-19, 2008.

[8] F. Akinsola and S. Ikhide, "Bank Lending to Small and Medium Scale Enterprises (SMEs) and Business Cycle in South Africa After The Global Financial Crisis," J. Dev. Areas; Nashv., vol. 53, no. 1, pp. 78, 80-94, 2019.

[9] M. S. Mathibe, V. Zyl, and J. H, "The Impact Of Business Support Services To SMMEs In South Africa.," Int. Bus. Econ. Res. J. (Online); Littlet., vol. 10, no. 11, 2011.

[10] H. Chahal, S. Mishra, S. Raina, and T. Soni, "A comprehensive model of business social responsibility (BSR) for small scale enterprises in Indian context," J. Small Bus. Enterp. Dev. Bradford, vol. 21, no. 4, pp. 716-739, 2014.

[11] D. Merchant, P.; Kumar, A.; Mallik, "Factors Influencing Family Business Continuity in Indian Small and Medium Enterprises (SMEs)," J. Fam. Econ. Issues; New York, vol. 39, no. 2, pp. 177-190, 2018.

[12] Ehiorobo O. A., "Employee Fidelity and the Survival of Micro and Small Scale Businesses in Nigeria.," Stud. Commer. Bratisl. Bratislava, vol. 13, no. 44, pp. 87-101, 2020 .

[13] A. Babajide, "Effects of Microfinance on Micro and Small Enterprises (MSEs) Growth in Nigeria," Asian Econ. Financ. Rev. Karachi, vol. 2, no. 3, p. 463, 2012.

[14] T.-W. Fu, K. Mei-Chu, and H. Yen-Sheng, "Capital growth, financing source and profitability of small businesses: Evidence from Taiwan small enterprises," Small Bus. Econ. Dordr., vol. 18, no. 4, pp. 257-167, 2002.

[15] D. N. Clark and H. Douglas, "Micro-enterprise growth: Lessons from home-based business in New Zealand.," Small Enterp. Res. Wellingt., vol. 21, no. 1, pp. 82-98, 2014.

[16] J. Xiao and H. Fu, "An empirical study of usage of external business services by Chinese SMEs,” J. Enterp. Inf. Manag. Bradford, vol. 22, no. 4, pp. 423-440, 2009.

[17] The Republic of Indonesia, "The Presidential Letters Number R-14/Pres/03/2021 regarding the Considerations for Changing Ministries in the Consultation Meeting of the Replacement Consultative Body (Bamus) of the DPR on April 8, 2021 and Presidential Decree Number 72/P/2021 concerning." 2021.

[18] Seto Sanjoyo, S. Sapriani, A. Setiawan, and S. Suroyya, "Seto Sanjoyo; Sapriani Sapriani; Agus Setiawan; Salma Suroyya;," Borneo Law Rev., vol. 4, no. 1, 2020.

[19] Edwar J. S., "Government Efforts in Realizing the Ease of Doing Business in Indonesia," Rechtsvinding Journal, Media Natl. Law Dev., vol. 6, no. 3, pp. 329-348, 2017.

[20] Hasrina R. and Yati N., "Legality of Cover Song Uploaded to Youtube," J. Al'Adl, vol. XII, no. 1, pp. 77-88, 2020.

[21] Abdul H. Barkatullah and Ifrani, "Balancing the Negative Impacts of Coal Mining Policy," J. Environ. Law Dev., vol. 3, no. 1, p. 35.

[22] Dadang S, A Guide to Making Business Contracts. Jakarta: Visimedia, 2017.

[23] The Republic of Indonesia, "Law Number 7 of 2014 concerning Trade (Law 7/2014) amended by Law Number 11 of 2020 concerning Job Creation, Article 106 paragraph (1).” 2014. 
